\title{
Analysis of the asymmetric impacts of oil prices on food prices in oil-exporting developing countries
}

\author{
Daniel Francois Meyer \\ North West University, South Africa \\ daniel.meyer@nwu.ac.za \\ Kazeem Abimbola Sanusi \\ North-West University, South Africa \\ sanusikazeemabimbola@yahoo.com \\ Adewale Hassan \\ North-West University, South Africa \\ adewale706@gmail.com
}

\begin{abstract}
This study focuses on the effects of oil price changes on food prices in oilexporting developing countries between 2001 and 2014. These effects in net food-importing and oil-exporting, developing countries have not received adequate attention in literature. The methodology included the application of a non-linear panel autoregressive distributed lag (ARDL) model. The bound testing cointegration analysis of the non-linear panel ARDL specification suggests the presence of co-integration among the variables: food prices, oil price, inflation, and trade openness. The estimated non-linear panel ARDL model indicated the presence of asymmetry in the behavior of food prices solely in the long run. More specifically, in the long run, there is a significant and positive relationship between oil price increases and food prices. Meanwhile, no long-run relation is found between oil price reduction and food prices. Furthermore, the model suggests the absence of asymmetry in the behavior of food prices in the short run, as the relations between both increase and reduction in oil price and food prices are found to be insignificant. The study, therefore, recommends that oil-exporting developing countries should adjust their public policy schemes in such a way as to enable reductions in the oil price to trickle down to food prices. In addition, these countries should ensure the implementation of long-term agricultural policies aimed at insulating their economies from global food crises that may arise due to oil price increases.
\end{abstract}

Keywords: ARDL model, asymmetry, developing countries, food prices, oil price.

JEL Classification: C23, E17 


\section{INTRODUCTION}

Top on the list of the Millennium Development Goals (MDGs) and Sustainable Development Goals (SDGs) is the eradication of extreme poverty and hunger; furthermore, in recent years, there has been growing global concern over oil price fluctuations and rising food prices (Balitskiy et al., 2014; Baumeister \& Kilian, 2014). Food prices have exhibited significant increases since the mid-2000s, just as the oil price continues to be volatile. The prices of corn, rice, and wheat as well as other crops have reached record highs, putting huge pressure on the majority of food-importing nations, especially developing countries, which are facing hikes in both food and energy prices within an increasingly fragile macroeconomic environment (Udoh \& Egwaikhide, 2012). The food crisis in the mid-2000s became a major source of concern for the world leaders. In June 2008, the United Nations (UN) organized the World Food Summit held in Rome, where many questions were raised about the causes of the food crisis and how to resolve it (Wise \& Murphy, 2012). Despite extensive literature on the factors contributing to high and volatile food prices, the relative importance of the effect of oil price changes on food price hikes have continued to be a contentious issue. It is therefore not surprising that along with the continued rise in food prices, oil price changes have been investigated as a potential cause, since it appears that increases in this price could also lead to food price increases and that a joint hike of these two prices could further worsen the situation (De Gregorio, Landerretche, Neilson, Broda \& Rigobon, 2007; Nagyová et al., 2016). By affecting the energy-intensive inputs such as fertilizers and fuel, which have direct impact on transportation costs, oil price changes directly affect food production costs and, subsequently, food prices (Baumeister \& Kilian, 2014). In addition, given the increasing costs of global food production, food import bills would soar during the times of rising oil prices for food-importing countries. Accordingly, this would further exert an upward pressure on domestic food prices (Konandreas, 2012).

Several studies have investigated the effects of oil price on food prices changes indifferent time periods. Following the excess co-movement hypothesis formulated by (Pindyck \& Rotemberg, 1990), some empirical studies have investigated whether the co-movement arises from common macroeconomic shocks or is due to herd behaviour speculation. Using OLS regressions to estimate the pass-through of changes in the oil price to the prices of other commodities, (Baffes, 2010) found that food commodities tend to move together with the oil price, even after controlling for macroeconomic variables. Correspondingly, (Vansteenkiste, 2009), utilizing a dynamic factor model, reported that various common macroeconomic factors cause the commodities' prices move together. As a result of their methods of analysis, these studies provide useful insights into the correlation between different commodity prices in the short run. However, they do not take the long run into account. Co-integration between price series suggest that two prices may behave in a different way in the short run, but that they will converge towards a common behavior in the long run (Barrett \& Li, 2002). Moreover, prices may drift apart in the short run due to policy changes, or seasonal factors, but economic forces such as market mechanisms may bring them together in the long run (Palaskas, 1995; Enders, 1995). For instance, Zhang, Lohr, Escalante, and Wetzstein (2009) discovered long-run relationship between oil and food prices, but in the short run, they found no relationship. The production of biofuel has been perceived as an explanation for the co-movement, especially between the prices of energy and food commodities in the long run (Arshad \& Hameed, 2009; Serra \& Zilbermann, 2013; Simionescu at al., 2017). For example, Campiche, Bryant, Richardon, \& Outlaw (2007) found corn and soybean prices in the US to be cointegrated with crude oil prices after the emergence of the biofuels market, with the oil price driving the feedstock prices.

A number of other studies have also documented the long-run effect of the oil price on food prices. The results have, however, varied. For example, (Gohin and Chantret, 2010) report positive long-run relationship between global prices of some food and energy products, due to cost-push effects. In addition, 
Balcombe and Rapsomanikis (2008) establish that oil prices are long-run drivers for sugar prices in Brazil, while Wixson and Katchova (2012) note that soybean prices are influenced by crude oil prices in the long run. These positions were reinforced by Zhang et al. (2009), Arshad and Hameed (2009), and Abdel and Arshad (2008), all of whom reported the oil price to be a long-run driver of food prices. However, in a similar study, Zhang, Lohr, and Wetzstein (2010) did not establish a direct long-run relationship between fuel and agricultural commodity prices. This is corroborated by Chakravorty, Hubert, Moreaux, and Nostbakken (2012) in a study of the long-run effect of the US and the EU mandatory biofuel mandates, these authors found no long-run relationship between oil and food prices.

Thus, the results from the various studies on the long-run effect of the oil price on food prices have been largely mixed. In addition, most of these existing studies have focused mainly on developed and oilimporting countries. The effect of the oil price on food prices in net food-importing and oil-exporting countries has not received adequate attention in literature. Furthermore, most of the existing studies examine the relationship between oil and food prices by means of the standard time series techniques of cointegration, error-correction technique and Granger causality. Although these techniques assist in evaluating their long-run relations, as well as their short-run interactions, they presume symmetric relations between oil and food prices and hence are not adequate in capturin the asymmetric effect of oil prices on the latter. To be more specific, the only available panel study on the effects of the oil price on food prices in oilexporting developing countries is the one published by (Olayungbo \& Hassan, 2016), who employed a panel ARDL model to analyze both long-run and short-run interactions between oil and food prices in the sample countries. Yet they did not take into consideration the possibility of asymmetry presence in the food-oil prices relationship. The remainder of the study is structured as follows: section two synthesizes the available empirical evidence. Section three outlines the empirical approach to the study, while section four presents the results. The last section concludes the study.

\section{LITERATURE REVIEW}

The relationship between the oil price and food prices has attracted much attention in public debate, especially since the food price crisis in 2007/2008 (Timmer, 2010). Campiche et al. (2007) examined the covariability between crude oil prices and corn, sorghum, sugar, soybeans, soybean oil, and palm oil prices using weekly data from 2003 to 2007 in the United States. A vector error correction model (VECM) was employed for the study. Their co-integration results indicate that corn and soybean prices were co-integrated with the crude oil price during the 2006-2007 time frame, but not during the 2003-2005 period. Further results from the same study make it clear that crude oil prices do not adjust to changes in the corn and soybean market. The study concluded that (through the biodiesel market) soybean prices seem to be more closely correlated to crude oil prices than corn prices. A similar study conducted by Yu, Bessler, and Fuller (2006) analyzed the co-integration and causality of higher crude oil prices with respect to the world food price and demand for vegetable oils. Applying co-integration method to weekly data from January 1999 to March 2006, they deduce that the influence of shocks in crude oil prices on the variation in food prices is relatively small and insignificant.

Trujillo-Barrera, Mallory, and Garcia (2012) examined volatility spillovers in the US from energy to agricultural markets using daily data from July 2006 to January 2011. Univariate TGARCH and bivariate VECM-BEKK-MGARCH models were employed in the study. These authors found significant spillovers from oil to corn and ethanol markets, which seem to be particularly strong in high volatility periods for oil markets. They also identified significant volatility spillovers from corn to ethanol markets. Additionally, Chen $e t$ al. (2010) modelled the relationship between the oil price and global food prices, using weekly data from March 1983 to February 2010, by means of an autoregressive distributed lag (ARDL) method. The 
results of their study revealed that any change in the grain price is significantly influenced by the changes in the crude oil price. In a similar vein, Esmaeili and Shokoohi (2010) investigated the co-movement of food prices and the macroeconomic index, employing a principal component analysis and VAR Granger causality test, utilising monthly data from 1961 to 2005 , to understand the influence of the macroeconomic index on food prices. Those studied were eggs, meat, milk, oilseeds, rice, sugar, and wheat, while the macroeconomic variables included the crude oil price, consumer price index and food price index. The study reports a correlation coefficient between the extracted principal component and the macroeconomic index to vary between 0.87 for the global GDP and 0.36 for the consumer price index. The researchers found that the food production index has the greatest influence on the macroeconomic index, but they did not establish a direct relationship between the oil price and the food price component. However, Natanelovet al. (2011) in a similar study on the relationship between the price of crude oil and world food prices, found a direct relationship between oil and food prices. A vector error correction model (VECM) was employed for the study, using monthly data on world crude oil, wheat, rice, sugar, soybean oil, cocoa, coffee and soybeans from July 1989 to February 2010. The results of the study indicate that changes in the oil price have significant effects on food prices in the long run.

While the positive link between oil and food prices is well established, as the literature reviewed indicates, existing empirical evidence is far from being uniform. In a study of the relationship between oil prices, exchange rates, and commodity prices in the United States, Harri, Nalley and Hudson (2009), applied a Vector Error Correction Model (VECM) monthly data for the period January 2000 to September 2008. They found that commodity prices are linked to oil for corn, cotton, and soybeans, but not for wheat, and that exchange rates do play a role in the linkage of prices over time. However, in a study of the relationship between the rising crude oil prices and an increase in the United States current account deficit, Abbott, Hurt and Tyner (2009) reported that steady oil price increases since 2004 and the consequent simultaneous depreciation in the value of the US dollar, relative to most other high and low-income countries' currencies, resulted in higher corn prices in the US, since the depreciating dollar had resulted in cheaper corn exports in places such as china and India.

In measuring the relative importance of global demand, speculation, and crude oil in explaining corn price volatility, McPhail, Du, and Muhammad (2012) used a structural vector autoregression (SVAR) and variance decomposition on monthly data from January 2000 to July 2011. The study found that speculation is the most important of the considered factors in explaining corn price variations, but Justin the short run. In the long-run, however, oil price is the most important factor explaining these variations. Additionally, Kratschell and Schmidt (2013), using the frequency domain Granger causality test of Breitung and Candelon (2006) to analyze short and long-run causality between energy prices and prices of food commodities in the US, found that the oil price Granger causes all the considered food prices. However, they also established that when controlling for business cycle fluctuations, this link exists especially at low frequencies. Thus, their study concluded that short-run phenomena, such as hard behaviour and speculation, do not seem to have a considerable effect on the studied food prices, but that the relation between oil and food prices is, rather, established by long-term developments.

Furthermore, Peri and Baldi (2010) applied a co-integration analysis based on Hansen and Seo (2002) and a Panel Vector Error Correction Model (PVECM) to weekly data on sunflower oil, rapeseed oil, soybean oil and diesel prices for several European countries during the period January 2005 to November 2007. They report that the co-integration relation of rapeseed and diesel prices is a case of threshold co-integration and that sunflower oil and soybean oil prices were not found to have ago-integration relation with diesel prices. However, they conclude that diesel prices affect food prices in the long run. Similarly, using several copula models with different conditional dependence structures and time-varying dependence parameters to analyse weekly data, Roboredo (2012) studied-movements between world oil prices and global prices for 
corn, soybean, and wheat. Empirical results from the study show weak oil-food dependence and no extreme market dependence between oil and food prices. The results support the neutrality of agricultural commodity markets towards the effect of changes in oil prices and non-contagion between the crude oil and agricultural markets. However, dependence increased significantly in the last three years of the sampling period, even though upper tail dependence remained insignificant, indicating that food price spikes are not caused by positive extreme oil price changes.

Lastly and in summary, the analysis of the literature review indicates mixed results regarding the relationship between oil price changes and food price changes, but overall, it is evident that oil prices increases cause food price changes. The trends of changes in oil price and food prices in the sampled countries are presented below. On the average, food prices rise faster following increases in oil price.

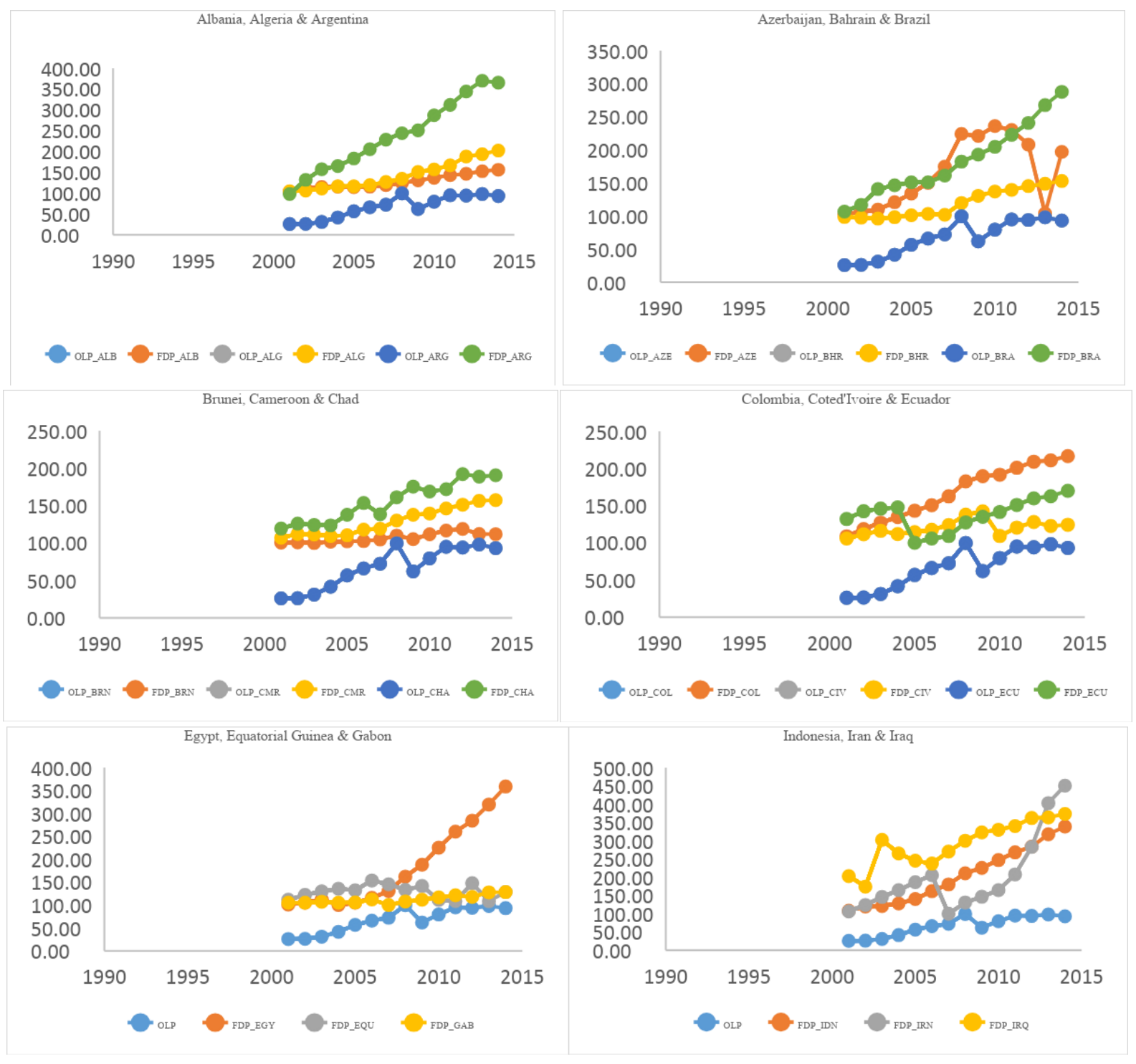




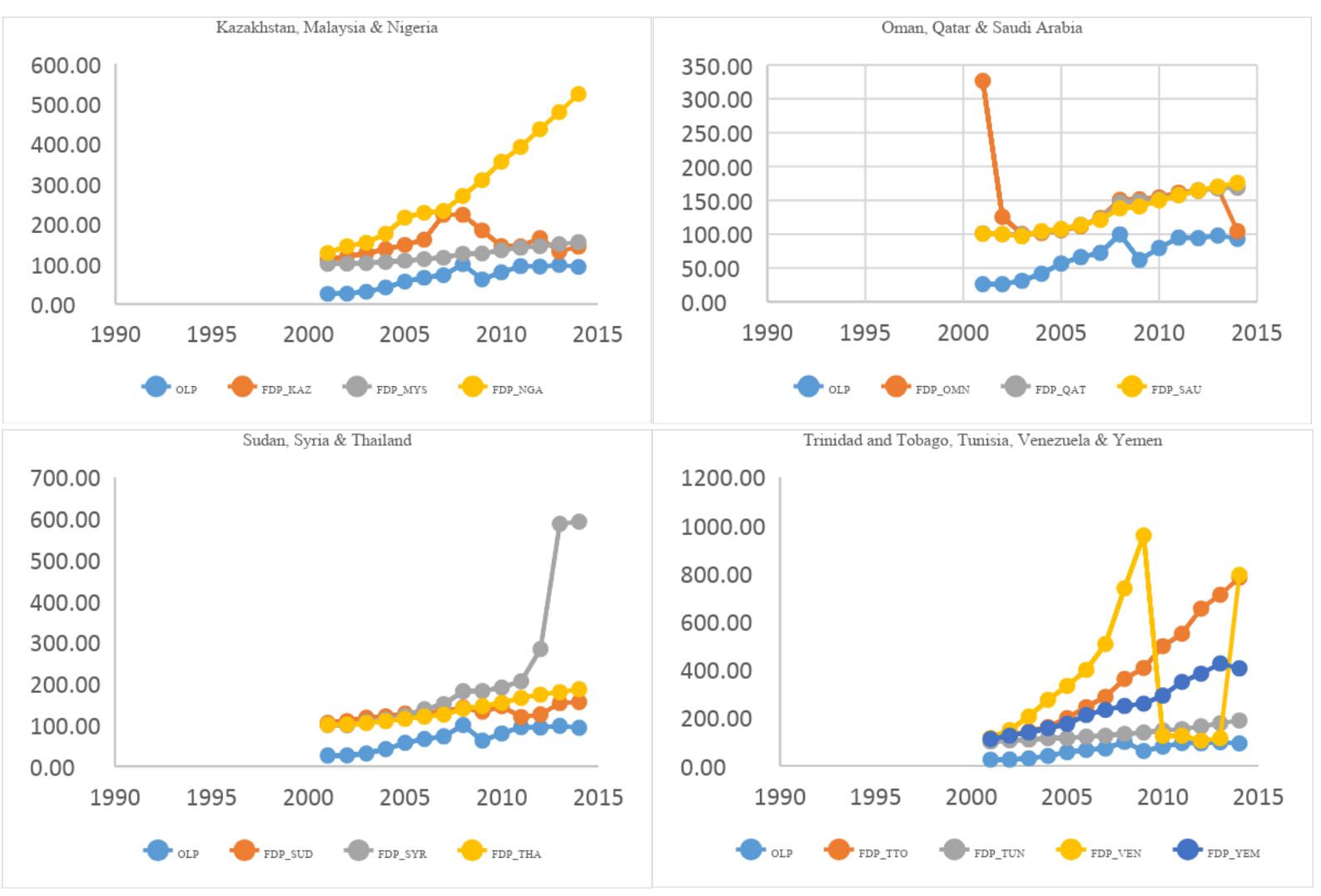

Figure 1. Trends of changes in oil price and food prices in the sampled countries

\section{METHODOLOGY AND DATA SOURCES}

In an attempt to investigate the relationship between the oil price and agricultural food prices in oilexporting developing countries, this study adopts a non-linear panel ARDL (NARDL) co-integration technique, which is an extension of the well-known ARDL approach by Pesaran et al. (2001), to capture both long-run and short-run asymmetries between variables. Public policy schemes, such as price floor and price ceiling, play an important role in oil-exporting developing countries (Gouel, 2013). The pricing schemes place a limit to how the price can adjust up or down which essentially validates the possibility of asymmetric relationships. One should also note the fact that the interplay between firms' cost structures and market power may account for both long-run and short-run asymmetries in price movements (Karantininis, et al.2011). Consequently, an assessment of the effect of the oil price on food prices in a panel of oil-exporting developing countries, by means of a non-linear technique to capture the asymmetric effect of oil price on food prices, becomes necessary. Therefore, this study utilizes a non-linear (asymmetric) Autoregressive Distributed Lag model as developed by Shin, Yu, and Greenwood-Nimmo (2014).

When compared with the classical co-integration models, NARDL models possess a number of very strategic advantages. First, they perform better in determining co-integration relations in small samples (Romily, Song and Liu, 2001). Secondly, they can be applied regardless of whether the regressors are stationary at the level or at first difference. However, they cannot be applied if the regressors are stationary at the second difference, as the presence of an I(2) variable renders the computed F-statistic for testing cointegration invalid. Thirdly, the NARDL framework is particularly suitable for this research problem as it allows for capturing both the long- and short-run asymmetries, and also for detecting hidden co-integration. 
Following Shin et al. (2014) and Ibrahim (2015), the following asymmetric long-run equation of food prices is:

$$
f d p_{i t}=\alpha_{0 i}+\alpha_{1 i} c p i_{i t}+\alpha_{2 i} t r d_{i t}+\alpha_{3 i} o l p_{i t}^{+}+\alpha_{4 i} o l p_{i t}^{-}+e_{i t}
$$

Where fdpis food prices, $c p i$ is the consumer price index to capture the effect of inflation, trd is the degree of trade openness, olpis oil price, and $\alpha\left({ }^{\alpha}, \alpha{ }^{\prime}, \alpha_{2 i}, \alpha_{3 i}, \alpha_{4 i}\right)$ is a vector of long-run parameters to be estimated. In (1), ${ }^{o l p_{i t}^{+}}$and ${ }^{o l p_{i t}^{-}}$are partial sums of positive and negative changes in ${ }^{o l} p_{i t}$ such that:

$$
o l p_{i t}^{+}=\sum_{i=1}^{t} \Delta o l p_{i}^{+}=\sum_{i=1}^{t} \max \left(\Delta o l p_{i}, 0\right)
$$

and

$$
o l p_{i t}^{-}=\sum_{i=1}^{t} \Delta o l p_{i}^{-}=\sum_{i=1}^{t} \min \left(\Delta o l p_{i}, 0\right)
$$

From the above equation, the long-run relation between food prices and oil price increases is $\alpha_{3 i}$, and it is expected to be positive. Meanwhile, ${ }^{\alpha^{4 i}}$ captures the long-run relation between food prices and oil price reduction. Since they are expected to move in the same direction, ${ }^{{ }^{4 i}}$ is expected to be positive. Following Shin et al. (2014), equation (1) can be framed in a Panel ARDL setting in line with Pesaran et al. (2001) as:

$$
\Delta f d p_{i t}=\alpha_{i}+\beta_{o i} f d p_{i, t-1}+\beta_{i i} c p i_{i, t-1}+\beta_{2 i} t r d_{i, t-1}+\beta_{3 i} o l p_{i, t-1}^{+}+\beta_{4 i j} o p_{i,-1}^{-}+\sum_{i=1}^{p} \rho_{i} \Delta f d p_{i, t-1}+\sum_{i=0}^{q} \delta_{i} \Delta c p_{i,-1}+\sum_{i=0}^{r} \vartheta_{i} \Delta r d_{i, t-1}+\sum_{i=0}^{s}\left(\phi_{i}^{+} \Delta o l p_{i, t-1}^{+}+\phi_{i}^{-} \Delta o l p_{i, t-1}^{-}\right)+\mu_{i t}
$$

where all variables are as earlier defined, $p, q, r_{\text {and }} s$ are lag orders, while ${ }^{\alpha_{3 i}}$ and ${ }^{\alpha_{4 i}}$, are the aforementioned long-run impacts of, respectively, oil price increase and oil price reduction on food prices. $\sum_{i=0}^{s} \phi_{i}^{+}$measure the short-run impacts of oil price increases on food prices while $\sum_{i=0}^{s} \phi_{i}^{-}$determines the shortrun impacts of oil price reduction on food prices. Within this framework, therefore, further to the asymmetric long-run relation, the asymmetric short-run impacts of oil price changes on food prices are also captured. Annual data sets of food prices, oil prices, CPI and the trade openness of 31 countries are employed in this paper. The sample countries are all oil-exporting developing countries, while the majority of them are net importers of food. They are Albania, Algeria, Argentina, Azerbaijan, Bahrain, Brazil, Brunei, Cameroon, Chad, Colombia, Cote d'Ivoire, Ecuador, Egypt, Equatorial Guinea, Gabon, Indonesia, Iran, Iraq, Kazakhstan, Malaysia, Nigeria, Oman, Qatar, Saudi Arabia, Sudan, Syria, Thailand, Trinidad and Tobago, Tunisia, Venezuela and Yemen. The study covers a period of 14 years, spanning 2001 to 2014. The choice of 2001 and 2014 as the starting and ending dates respectively is informed by the availability of data on food prices for all the countries. Moreover, this period witnessed huge fluctuations in the price of crude oil.

Food prices, measured by the food price index, offer a measure of the monthly change in international prices of a basket of food commodities. The index consists of the average of five commodity group price indices weighted with the average export shares of each of the groups. It comprises the cereal price index, vegetable oil price index, meat price index, sugar price index and dairy price index. The food price index is sourced from the United Nations (2016), the database of the Food and Agricultural Organization (FAO) of the United Nations. Oil price is the price at which crude oil is sold in the international market. This is 
sourced from the US Energy Information Administration (2016). Data on inflation, measured by the consumer price index, which reflects the annual percentage change in the cost to the average consumer, of acquiring a basket of goods and services, that may be fixed or changed at specified intervals, such as yearly, as well as those on trade openness are sourced from the WDI (2016) of the World Bank.

\section{RESULTS AND DISCUSSION}

Table 1 presents the descriptive statistics of the variables included in the study. It can be observed that the mean and median of oil price and inflation rate are very close, which implies that their distributions are nearly symmetrical. This is an indication of the existence of low variability. The skewness statistics show that three of the variables: food prices, inflation, and trade openness, are positively skewed, while crude oil price is negatively skewed. The Jarque-Beta probability values for all the variables are below the 0.05 critical level. This suggests a rejection of the null hypothesis of normal distribution for all the variables at 5 percent level of significance. The absence of normal distribution may result from the cross-sectional and heterogeneous nature of the data employed in the study. Such heterogeneities are, however, corrected for in the panel data analysis.

Table 1

Descriptive statistics of variables

\begin{tabular}{|l|c|c|c|c|}
\hline Variable & Food price index (fdp) & $\begin{array}{c}\text { Crude oil price } \\
\text { index (olp) }\end{array}$ & CPI & $\begin{array}{c}\text { Trade openness } \\
\text { (trd) }\end{array}$ \\
\hline Mean & 169.7358 & 65.21462 & 87.4927 & 83.57805 \\
\hline Median & 138.3 & 66.05 & 88.74706 & 78.22787 \\
\hline Maximum & 958.3 & 99.67 & 214.6947 & 351.1057 \\
\hline Minimum & 96.2 & 25.98 & 21.13188 & 18.03959 \\
\hline Std. Dev. & 99.0868 & 26.49265 & 23.36525 & 42.75723 \\
\hline Skewness & 3.438612 & -0.183546 & 0.642289 & 1.813938 \\
\hline Kurtosis & 19.62693 & 1.638675 & 7.10764 & 9.151667 \\
\hline Jarque-Bera & 5436.318 & 33.38119 & 311.0295 & 856.4503 \\
\hline Probability & 0.000000 & 0.000000 & 0.000000 & 0.000000 \\
\hline Sum & 68403.52 & 26281.49 & 35259.56 & 33681.96 \\
\hline Sum Sq. Dev. & 3946914 & 282148 & 219465.9 & 734928.8 \\
\hline
\end{tabular}

While the ARDL approach to co-integration is applicable, regardless of whether the variables are integrated at levels $(\mathrm{I}(0))$ or at first difference $(\mathrm{I}(1))$, it is still necessary to carry out unit root tests, to ensure that no I(2) variable is involved, as the presence of the latter renders the computed F-Statistic for testing co-integration invalid. To this end, the results of the Levin, Lin \& Chu (LLC), I'm, Pesaran, and Shin (IPS), Augmented Dickey-Fuller (ADF), and Phillips Peron (PP) panel unit root tests conducted on the variables are presented in Table 2. The individual intercept was included in the test equation for each of the unit root tests, while the lag length for each variable was automatically selected by the Schwarz Information Criterion (SIC).

In the tests captured in Table 2, all of the four tests (LLC, IPS, ADF, and PP) are in agreement that all the variables are integrated at first difference $(\mathrm{I}(1))$ at one percent level of significance. The only exceptions to this are: the oil price, being stationary at level $(\mathrm{I}(0))$, according to LLC just at the one percent level, as well as trade openness, being stationary at level $(\mathrm{I}(0))$, according to both LLC and PP, at the one percent level. 
Panel unit root tests

\begin{tabular}{llllllllll}
\hline Variable & Level & LLC & P-v & IPS & P-v & ADF & P-v & PP & P-v \\
\hline fdp & 0 & 8.66 & 1.00 & 8.83 & 1.00 & 18.39 & 1.00 & 31.69 & 0.99 \\
& 1 & -2.03 & $0.02^{*}$ & -2.56 & $0.01 *$ & 105.52 & $0.00^{*}$ & 182.38 & $0.00^{*}$ \\
olp & 0 & -5.69 & $0.00^{*}$ & 1.89 & 0.97 & 25.04 & 1.00 & 18.29 & 1.00 \\
& 1 & -15.89 & $0.00^{*}$ & -9.92 & $0.00^{*}$ & 210.95 & $0.00^{*}$ & 645.27 & $0.00^{*}$ \\
\multirow{2}{*}{ cpi } & 0 & 4.58 & 1.00 & 9.58 & 1.00 & 12.99 & 1.00 & 16.69 & 1.00 \\
& 1 & -2.55 & $0.01 *$ & -2.69 & $0.00^{*}$ & 106.63 & $0.00^{*}$ & 215.39 & $0.00^{*}$ \\
\multirow{2}{*}{$\operatorname{trd}$} & 0 & -2.01 & $0.02^{*}$ & -0.74 & 0.23 & 65.62 & 0.35 & 106.60 & $0.00^{*}$ \\
& 1 & -6.17 & $0.00^{*}$ & -5.71 & $0.00^{*}$ & 136.18 & $0.00 *$ & 335.48 & $0.00^{*}$ \\
\hline
\end{tabular}

$*$ represents $1 \%$ level of significance, while P-v indicates a probability value

Since the panel unit root tests indicate that none of the variables is $\mathrm{I}(2)$, the bounds testing procedure could proceed. Table 3 reports the bounds F-Statistic and the critical value bounds for the F-statistic, as provided by Pesaran et al. (2001). As presented in the table, the value of the computed F-statistic (32.358) exceeds the upper bound critical value of the bounds testing table, which stands at 4.01 at 5 percent level of significance. The null hypothesis of no co-integration is thus rejected. The conclusion is that the four variables, i.e. food prices, oil price, inflation, and trade openness, co-move in the long run.

Table 3

Bounds test for nonlinear co-integration

\begin{tabular}{|c|c|c|c|}
\hline F-Statistic & $95 \%$ lower bound & $95 \%$ upper bound & Conclusion \\
\hline 32.358 & 2.86 & 4.01 & Co-integration \\
\hline
\end{tabular}

Following the estimation of equation (4), the non-linear panel ARDL long-run estimates are presented in Table 4. As indicated in the table, the long-run coefficient of inflation rate is positive and significant at one percent significance level, as should be expected. It suggests that a unit increase in the inflation rate in the sample countries, is related to an increase in food prices by approximately 1.4 units, holding other variables constant. This result reaffirms the position of Adam et al. (2012), who suggested a positive relationship between food prices and inflation in the long run. In the case of trade openness, Table 4 illustrates that its long-run coefficient is significant, but negative at one percent significance level. It further implies that a unit increase in the degree of trade openness in the sample countries is related to a decrease in food prices by almost 0.35 units, holding other variables constant. This result indicates that food products become more competitive when sample countries open up their international trading activities and that such competitiveness leads to a reduction in the prices of food commodities. This position supports that of Herath (2014) who reported a significant, but negative, effect of degree of trade openness on food prices in Sri Lanka.

Regarding the main objective of the study, the results in Tables 4 and 5 indicate an asymmetric longrun relation between oil price and food prices, with the increase in oil price being significantly related to food prices, while the reduction in oil price is not. The estimates suggest that a unit increase in the price of oil is associated with the increase in food prices by 0.42 units. This result corroborates the findings of Ibrahim (2015) which affirm the presence of asymmetry in the long-run oil price - food price relation in Malaysia, with a significant and positive long-run relation between oil price increases and food price, and an absence of a long-run relation between oil price reduction and the food price movements. Furthermore, as 
indicated in Table 4, the long-run relation between oil price decrease and food prices is insignificant, which suggests that reductions in the price of oil have no effect on food prices in the sample countries. This finding should be worrying because, while a drastic oil price increase is positively related to changes to food prices in the long-run, its reduction does not translate into a reduction in food prices in the sampled countries. In other words, following an initial increase in food prices as a result of oil price hikes, the high food prices will remain at those levels, even if the oil price has corrected downward after the initial increase.

Nonlinear panel ARDL long-run estimates

\begin{tabular}{|c|c|c|c|c|}
\hline Variable & Coefficient & Std. Error & t-Statistic & P-value \\
\hline$c p i$ & 1.375466 & 0.129505 & 10.62092 & $0.0000^{*}$ \\
\hline$t r d$ & -0.346764 & 0.087550 & -3.960761 & $0.0001^{*}$ \\
\hline olp $^{+}$ & 0.418914 & 0.058672 & 7.139934 & $0.0000^{*}$ \\
\hline olp $^{-}$ & 0.030125 & 0.037717 & 0.798716 & 0.4255 \\
\hline
\end{tabular}

$*$ denotes $1 \%$ level of significance

Test for asymmetry

\begin{tabular}{|c|c|c|}
\hline F-Statistic & P-value & Conclusion \\
\hline 74.15029 & $0.0000^{*}$ & Asymmetry \\
\hline
\end{tabular}

$*$ indicates $1 \%$ level of significance

For the short-run, the results as presented in Table 6 provide evidence of no asymmetric relationship between oil price and food prices. In fact, the findings indicate that a short-run relation between oil price increases and food prices are absent. This also reveals that the short-run relationship between oil price reduction and food prices is insignificant. This finding is consistent with that of Zhang et al. (2009) who found no relationship between oil price and global food prices in the short-run. It also corroborates the position of Arshad and Hameed (2009) who deny the existence of a short-run relationship between oil price and cereal prices in Thailand and United States (US).This finding, however, contradicts those of a study by Ibrahim (2015) which provided evidence for the presence of asymmetry in the short-run relation between oil price and food price in Malaysia. The volatility of the oil price in the world market may be an explanation for the inability of this price to affect food prices in the short-run. Furthermore, the findings in Table 6 suggest a positive and significant relationship between the inflation rate and food prices in the short run, at $1 \%$ significance level. In particular, it is affirmed that a unit increase in the inflation rate would lead to an increase in food prices by roughly 2.61 units. Nonetheless, on the other hand, the relationship between trade openness and food prices is found to be absent in the short-run, as Table 6 indicates an insignificant relationship between the two variables in the short run.

Table 6

Non-linear panel ARDL short-run estimates

\begin{tabular}{|c|l|l|l|l|}
\hline Variable & Coefficient & Std. Error & t-Statistic & P-value \\
\hline$\Delta c p i(-1)$ & 2.607277 & 0.792941 & 3.288109 & $0.0012^{*}$ \\
\hline$\Delta \operatorname{trd}(-1)$ & -0.602996 & 1.048262 & -0.575234 & 0.5658 \\
\hline$\Delta$ olp $^{+}(-1)$ & -0.032762 & 0.302669 & -0.108245 & 0.9139 \\
\hline$\Delta$ olp $^{-}(-1)$ & 0.055498 & 0.293165 & 0.189307 & 0.8501 \\
\hline
\end{tabular}

$*$ denotes $1 \%$ level of significance 


\section{CONCLUSION}

In this study, the effect of the oil price on food prices in oil-exporting, developing countries are examined. The majority of the countries included in the study are net food-importing countries. From the analysis, evidence of the presence of asymmetry in the long-run oil price-food prices relation was discovered, while asymmetry was found to be absent in the short-run relationship. The result concludes that oil price increase tends to lead to increases in food prices, while oil price reduction does not seem to be related to food price reductions in the long run. However, neither the oil price increase nor reduction seems to be related to food prices in the short-run. Based on the findings of this study, it is recommended that oilexporting developing countries should formulate and implement long-term agricultural policies to insulate their economies from future global food crises that may arise from oil price changes. It is also recommended that they utilize the additional revenue accruing from the upward movement in oil price to galvanize their agricultural sectors with a view to transforming their economies from net food-importing to net foodexporting countries, as this would go a long way in protecting them from the negative impact of oil price increase on food prices. As noted earlier that reduction in oil price does not affect the food prices in the sampled countries, it is hereby recommended that oil-exporting countries should also devise a means to ensure stability of oil price

This study also affirms a positive significant effect of inflation on food prices both in the long and short-run. Hence, monetary authorities in the sampled countries should ensure price stability. Lastly, trade openness is found to affect food prices negatively in the long run. Consequently, unbridled openings of the economy especially in the aspect of agricultural food products should be avoided.

\section{REFERENCES}

Abdel, H. A., \& Arshad, F. M. (2008). The impact of petroleum prices on vegetable oils prices: evidence from Cointegration Tests. Paper presented at the International Borneo Business Conference on Global Changes, Malaysia, December 2008.

Abott, P. C., Hurt, C., \& Tyner, W.E. (2009). What's driving food prices? Farm Foundation Issue Report (FFIR), Oak Brook, IL.

Adam, C., Kwimbere, D., Mbowe,. W. \& O’Connell. S. (2012). Food prices and inflation in Tanzania. A Bank of Tanzania Working paper S-40001-TZA-1.

Arshad, F. M., \& Hameed, A. A. A. (2009). The long-run relationship between petroleum and cereals prices. Global Economy and Finance Journal, 2(2), 91-100.

Baffes, J. (2010). More on the energy/non-energy commodity price link. Applied Economics Letters, 17(16), 1555-1558.

Balcombe, K., \& Rapsomanikis, G. (2008). Bayesian estimation of nonlinear vector error correction models: the Case of sugar-ethanol-oil nexus in Brazil. American Journal of Agricultural Economics, 90, 658-668.

Balitskiy, S., Bilan, Y., \& Strielkowski, W. (2014). Energy security and economic growth in the European Union. Journal of Security \& Sustainability Issues, 4(2), 123-130.

Baumeister, C. \& Kilian, L. (2014). Do oil price increases cause higher food prices?. Economic Policy, 29(80), 691-747.

Barrett, C. B., \& Li, J. R. (2002). Distinguishing between equilibrium and integration in spatial price analysis. American Journal of Agricultural Economics, 84, 292-307.

Breitung, J., \& Candelon, B. (2006). Testing for short- and long-run casualty: a frequency domain approach. Journal of Econometrics, 132, 363-379.

Campiche, J., Bryant, H., Richardson, J., \& Outlaw, J. (2007). Examining the evolving correspondence between petroleum prices and agricultural commodity prices. Paper presented at the American Agricultural Economics Association annual meeting. Portland, OR, July 29-August 1, 2007.

Chakravorty, U., Hubert, M., Moreaux, M., \& Nostbakken, L. (2012). The long-run impact of biofuels on food prices. Typescript. University of Alberta and Tufts University.

Chen, S., Kuo, H., \& Chen, C. (2010). Modelling the relationship between the oil price and global food prices. Applied Energy, 87(7), 2517-2525. 
De Gregorio, J., Landerretche, O., Neilson, C., Broda, C., \& Rigobon, R. (2007). Another pass-through bite the dust? In Oil prices and inflation [with comments]. Economica, 7 (2), 155-208.

Enders, W. (1995). Applied Econometric Time Series. New York: John Willey and Sons Inc.

Esmaeili, A., \& Shokoohi, Z. (2010). Assessing the effect of oil price on world food prices: application of principal component analysis. Energy Policy, 39 (2011), 1022-1025.

Gohin, A. and Chantret, F. (2010). The long-run impact of energy prices on world agricultural markets: The role of macro-economic linkages. Energy Policy, 38, 333-339.

Gohin, A., \& Chantret, F. (2010). The long-run impact of energy prices on world agricultural markets: the role of macro-economic linkages. Energy Policy, 38, 333-339.

Gouel, C. (2013). Food price stability and domestic stabilization policies in developing countries (No. w18934). National Bureau of Economic Research.

Hansen, B.E., \& Seo, B. (2002). Testing for two-regime threshold cointegration in vector error-correction models. Journal of Econometrics, 110, 293-318.

Harri, A., Nalley, L., \& Hudson, D. (2009). The relationship between oil, exchange rates, and commodity prices. Journal of Agricultural and Applied Economics, 41(2), 501-510.

Herath, H. M. S. P. (2014). Has trade liberalization improved food security? A comparative study on China and Sri Lanka. European Journal of Business and Management, 6 (18), 62-67.

Ibrahim, M. H. (2015). Oil and food prices in Malaysia: a nonlinear ARDL analysis." Agricultural and Food Economics 3:2. A springer Open Journal.

Karantininis, K., Katrkylidis, K., \& Persson, M. (2011). Price transmission in the Swedish porkchain: asymmetric nonlinear ARDL. Paper presented at the EAAE Congress: Challenges and Uncertainty, September 2, 2011, Zurich, Switzerland.

Konandreas, P. (2012). Trade policy responses to food price volatility in poor net food-importing countries. ICTSD Programme on Agricultural Trade and Sustainable Development. Issue Paper No. 42. Geneva: International Centre for Trade and Sustainable Development.

Kratschell, K., \& Schmidt, T. (2013). Long-run trends or short-run fluctuations - what establishes the correlation between oil and food prices?" In: Annual Conference 2013 (Duesseldorf): Competition Policy and Regulation in a Global Economic Order.

McPhail, L. L., Du, X., \& Muhammad, A. (2012). Disentangling corn price volatility: the role of global demand, speculation, and energy. Journal of Agricultural and Applied Economics, 44, 3(August 2012), 401-410.

Nagyová, L., Holienčinová, M., Rovný, P., Dobák, D., \& Bilan, Y. (2016). Food security drivers: Economic sustainability of primary agricultural production in the Slovak Republic. Journal of Security and Sustainability Issues, 6(2), 259-274.

Natalenov, V., Alam, M. J., McKenzie, A. M., \& Van Huylenbroeck, G. (2011). Is there co-movement of agricultural commodities futures prices and crude oil? Energy Policy 39, 4971-4984.

Olayungbo, D., \& Hassan, W. (2016). Effects of oil price on food prices in developing oil-exporting countries: a panel autoregressive distributed lag analysis. OPEC Energy Review. Special Edition: The Impact of the Oil Price on the global economy. 40(4), 397-411.

Palaskas, T. B. (1995). Statistical analysis of price transmission in the European Union. Journal of Agricultural Economics, 46, 60-69.

Peri, M., \& Baldi, L. (2010). Vegetable oil market and biofuel policy: an asymmetric cointegration approach. Energy Economics, 32, 687-693.

Pesaran, M. H., Shin, Y., \& Smith, R. J. (2001). Bounds testing approaches to the analysis of level relationships. Journal of Applied Econometrics, 16, 289-326.

Pindyck, R. S., \& Rotemberg J. J. (1990). The excess co-movement of commodity prices. Economic Journal, 100(403), 1173-1189.

Roboredo J. C. (2012). Do food and oil Prices co-move? Energy Policy, 49, 456-467.

Romily, P., Song, H., \& Liu, X. (2001). Car ownership and use in Britain: a comparison of the empirical results of alternative cointegration estimation methods and forecasts. Applied Economics, 33(14), 1803-1818.

Serra, T., \& Zilberman, D. (2013). Biofuel-related price transmission literature: a review. Energy Economics, 37, $141-151$.

Shin, Y., Yu, B., \& Greenwood-Nimmo, M. (2014). Modeling asymmetric cointegration and dynamic multipliers in a nonlinear ARDL framework. In Festschrift in Honor of Peter Schmidt (pp. 281-314). Springer New York. 
Simionescu, M., Albu, L. L., Raileanu Szeles, M., \& Bilan, Y. (2017). The impact of biofuels utilisation in transport on the sustainable development in the European Union. Technological and Economic Development of Economy, 23(4), 667-686.

Timmer, C. P. (2010). Reflections on food crises past. Food policy, 35(1), 1-11.

Trujillo-Barrera, A., Mallory, M., \& Garcia, P. (2012). Volatility spillovers in US crude oil, ethanol, and corn futures markets. Journal of Agricultural and Resources Economics, 37, 247-262.

United Nations (UN) Food and Agriculture Organization of the United Nations. (2016). Retrieved 05/01/2018 from http://www.fao.org/faostat/en/\#home.

The United States Energy Information Administration. (2016). Independent Statistics and Analysis. Retrieved 10/01/2018 from https://www.eia.gov/.

Vansteenkiste, I. (2009). How important are common factors in driving non-fuel commodity prices? - a dynamic factor analysis. ECB Working Paper Series 1072.

Wise, T.A., \& Murphy, S. (2012).Resolving the food crisis: assessing global policy reforms since 2007. Global Development and Environment Institute (GDEI).

Wixson. S. E., \& Katchova, A. E. (2012). Price asymmetric relationships in commodity and energy markets. Paper presented at the 123th European Association of Agricultural Economists' Seminar, Price Volatility and Farm Income Stabilization, Dublin, February 23-24, 2012.

World Bank. World Development Indicators I Data - World Bank Data (2016). Retrieved 08/01/2018 from: https: / / data.worldbank.org/products/wdi.

Yu, T. H., Bessler, D., \& Fuller, S. (2006). Cointegration and causality analysis of world vegetable oil and crude oil prices. Paperpresented at the American Agricultural Economics Association Annual Meeting, Long Beach, California, July 23-26, 2006.

Zhang, Z., Lohr, L., Escalante, C., \& Wetzstein, M. (2009). Ethanol, corn and soybean price relation in a volatile vehicle-fuels market. Energies, 2, 320-339.

Zhang, Z., Lohr L., \& Wetzstein M. (2010). Food versus fuel: what do prices tell us? Energy policy, 38(1), 445-51. 